\title{
Peran Guru Pendidikan Agama Islam dalam Meningkatkan Perilaku Islami Siswa di SD Negeri 01 Indralaya
}

\author{
${ }^{*}$ Cittra Juniarni $^{1, a^{*}}$, Abdallah $^{2, b}$, Helyani ${ }^{3, c}$ \\ ${ }^{1}$ IAIQI Indralaya Ogan Ilir, Sumatera Selatan, Indonesia \\ ${ }^{2}$ Mahasiswa PPs IAIQI Indralaya, Sumatera Selatan, Indonesia \\ ${ }^{3}$ Guru SD 16 Indralaya Selatan, Sumatera Selatan, Indonesia \\ Email: citrajuniarni@ymail.com $;$; syafeiabdallah@ gmail.com ${ }^{\mathrm{b}}$; ${ }^{3}$ helyanirosidin@ @ahoo.com ${ }^{\mathrm{c}}$
}

\begin{abstract}
Islamic Religious Education teachers are expected to be able to teach, guide, and provide good examples to students on how to behave properly. The role of Islamic Religious Education teachers has a central position in shaping student behavior in schools, if teachers are able to direct students to behave Islamically, it is not impossible in the school to create a culture of Islamic behavior. This research uses descriptive qualitative research. The data obtained are in the form of primary and secondary data. The data analysis used is data reduction, data presentation and conclusion drawing as the final result of this research. The research results obtained are as follows: First, namely the Role of Islamic Religious Education Teachers in Improving Students' Islamic Behavior at SD Negeri 01 Indralaya including: a. using the lecture method and the habituation method, b. maximize religious facilities in schools, c. Cultivate 5S, d. always try to set a good example or role model for students. Second, the supporting factors of Islamic religious education teachers in improving the Islamic behavior of students at SD Negeri 01 Indralaya are: a. there is cooperation between teachers; $b$. the participation of parents of students; c. sanctions for students who violate. While the inhibiting factors are: a. the absence of a prayer room so that the process of forming Islamic behavior is hampered; b. lack of books on Islamic studies.
\end{abstract}

Keywords: Teachers, Islamic Religious Education, Islamic Behavior

\begin{abstract}
Abstrak
Guru Pendidikan Agama Islam diharapkan mampu mengajarkan, membimbing, dan memberikan tauladan yang baik kepada siswa tentang bagaimana berperilaku yang baik. Peran guru Pendidikan Agama Islam memiliki posisi sentral dalam membentuk perilaku siswa di sekolah, jika guru mampu mengarahkan siswa untuk berperilaku islami, bukan tidak mungkin di sekolah tersebut tercipta budaya perilaku Islami. Penelitian ini menggunakan penelitian deskriptif kualitatif.Data yang diperoleh berbentuk data primer dan sekunder. Adapun analisa data yang digunakan ialah reduksi data, penyajian data dan penarikan kesimpulan sebagai hasil akhir terhadap penelitian ini. Hasil penelitian yang diperoleh sebagai berikut: Pertama, yakni Peran Guru Pendidikan Agama Islam dalam Meningkatkan Perilaku Islami Siswa di SD Negeri 01 Indralaya meliputi: a. menggunakan metode ceramah dan metode pembiasaan, $b$. memaksimalkan fasilitas keagamaan di sekolah, c.Membudayakan 5S, d.selalu berusaha memberikan contoh yang baik atau teladan bagi siswa. Kedua, Faktor pendukung guru pendidikan agama Islam dalam meningkatkan perilaku Islami siswa di SD Negeri 01 Indralaya ialah: a. ada kerjasama antar guru; b. adanya partisipasi orang tua siswa; c. adanya sanksi bagi siswa yang melanggar. Sedangkan faktor penghambatnya ialah: a. tidak adanya musholla sehingga proses pembentukan perilakau islami terhambat; b. minimnya buku kajian-kajian islami.
\end{abstract}

Kata Kunci: Guru, Pendidikan Agama Islam, Perilaku Islam

\section{Cara mensitasi artikel ini:}

Juniarni, C., Abdallah, A., \& Helyani, H. (2022). Peran guru pendidikan agama Islam dalam meningkatkan perilaku islami siswa di SD Negeri 01 Indralaya. Mitra PGMI: Jurnal Kependidikan MI, 8(1), 8-20. https://doi.org/10.46963/mpgmi.v8i1.405 
Citra Juniarni, Abdallah, Helyani

Peran Guru Pendidikan Agama Islam dalam Meningkatkan Perilaku Islami Siswa di SD Negeri 01 Indralaya

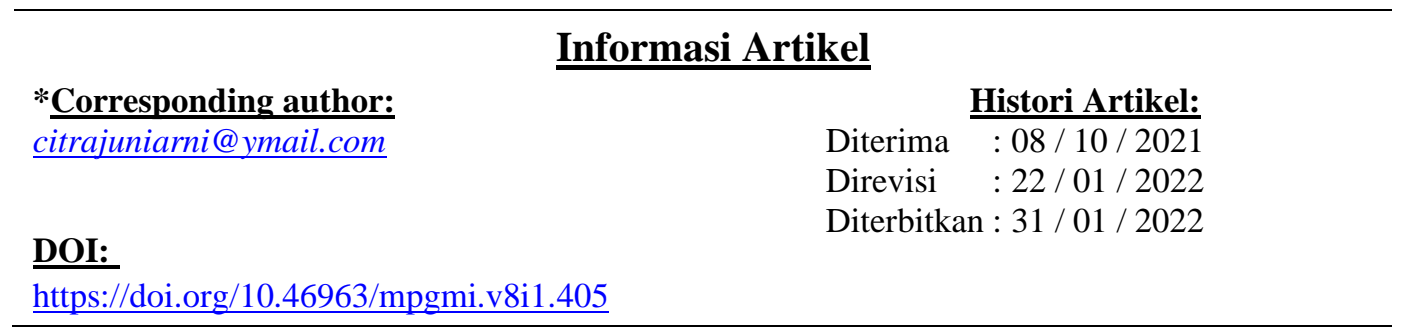

\section{PENDAHULUAN}

Pendidikan formal pada era reformasi dewasa ini, nampaknya senantiasa lebih ditingkatkan pada segi kualitas guru, di mana guru senantiasa dipacu untuk lebih meningkatkan keprofesionalismeannya, demikian juga dalam hal upaya peningkatan kualitas pembentukan perilaku siswa sebenarnya tidak terlepas dari pendekatan dalam proses belajar mengajar, karena baik tidaknya proses belajar mengajar dilihat dari mutu lulusan, dari produknya, atau proses belajar mengajar dikatakan berhasil apabila menghasilkan banyak lulusan yang berperilaku baik dan berprestasi tinggi. Proses belajar mengajar adalah suatu proses, tidak hanya mendapatkan informasi dari guru, tetapi banyak kegiatan atau tindakan, terutama jika diinginkan perilaku yang lebih baik pada diri siswa. Belajar pada intinya tertumpu pada kegiatan memberikan kemungkinan kepada para siswa agar terjadi proses belajar yang efektif. Atau dapat mencapai prestasi yang menggembirakan sesuai dengan tujuan pembelajaran.

Apakah memungkinkan terbentuk perilaku Islami pada diri siswa tersebut?. Dalam pengelolaan interaksi belajar mengajar, guru harus menyadari, bahwa pendidikan agama Islam tidak hanya dirumuskan dari sudut normatif, pelaksanaan interaksi belajar mengajar adalah untuk menanamkan suatu nilai ke dalam diri siswa. Sedangkan proses teknik adalah sebuah kegiatan praktik yang berlangsung dalam suatu masa untuk menanamkan nilai tersebut ke dalam diri siswa, yang sekaligus untuk mencapai tujuan yang telah ditetapkan. Akhir dari proses interaksi belajar mengajar diharapkan siswa merasakan perubahan-perubahan dalam dirinya (Syaiful Bahri (Djamarah, 1994)

Aktifitas kependidikan Islam timbul sejak adanya manusia itu sendiri (Nabi Adam dan Hawa), bahkan ayat yang pertama kali diturunkan kepada Nabi Muhammad Saw adalah bukan perintah tentang shalat, puasa, dan lainnya, tetapi justru perintah iqra' (membaca, merenungkan, menelaah, meneliti, atau mengkaji) atau perintah untuk mencerdaskan kehidupan manusia yang merupakan inti dari aktivitas pendidikan. Dari situlah manusia memikirkan, menelaah dan meneliti bagaimana pelaksanaan pendidikan itu, sehingga muncullah pemikiran dan teoriteori pendidikan Islam (Muhaimin, 2006) . Pendidikan agama Islam merupakan salah satu jenis pendidikan yang didesain dan diberikan kepada peserta didik yang

$9 \quad$ Print - ISSN: 2443-0021

Online - ISSN: 2716-4136 
beragama Islam dalam rangka untuk mengembangkan keberagamaan Islam mereka (Juniarni, 2018).

Tohirin menguraikan, Islam mengajarkan agar umatnya terus belajar selagi masih ada kesempatan dan sebelum jasad bersatu dengan tanah. Islam tidak saja mencukupkan pada anjuran supaya belajar, bahkan menghendaki supaya seorang itu terus menerus melakukan pembahasan, research dan studi. Rasulullah Saw, dalam hadis-nya menyatakan; "seseorang itu dapat dianggap seorang yang alim dan berilmu, selama ia masih terus belajar, apabila ia menyangka bahwa ia sudah serba tahu, maka ia sesungguhnya seorang jahil (bodoh)" (Tohirin, 2006).

Memang tidak mudah dan banyak sekali kendala-kendala yang dijumpai Guru Agama Islam ketika berhadapan langsung dengan anak didik. Kalau dilihat dari kenyataan anak di tingkat menengah atas atau sekolah kejuruan sangat minim sekali pengetahuan tentang agamanya. Minimnya pengetahuan tentang agama membuat anak kebanyakan sering semaunya sendiri dan mengacuhkan pelajaran Pendidikan Agama Islam, sehingga prestasi belajar mata pelajaran Pendidikan Agama Islam pun menjadi kurang begitu baik. Pendidikan agama Islam, yakni upaya mendidik kan agama Islam atau ajaran Islam dan nilai-nilai nya agar menjadi way of life (pandangan dan sikap hidup) seseorang (Muhaimin, 2006).

Pendidikan dan pengajaran ilmu Agama Islam sangatlah penting dan dibutuhkan oleh semua umat manusia, oleh karena itu semua haruslah ditanamkan sejak masih kecil atau sedini mungkin agar mereka mempunyai penanaman dasar yang kuat sehingga terwujudlah generasi muda yang bisa dibanggakan oleh bangsa dan Negara. Derasnya arus informasi yang berkembang di masyarakat menuntut setiap orang untuk bekerja keras agar dapat mengikuti dan memahaminya, kalau tidak kita akan ketinggalan jaman. Demikian halnya dalam pembelajaran di sekolah, untuk memperoleh yang optimal dituntut tidak hanya mengandalkan terhadap apa yang ada di dalam kelas, tetapi harus mampu dan mau menelusuri aneka ragam sumber belajar yang diperlukan. Guru dituntut tidak hanya mendaya gunakan sumber-sumber belajar yang ada disekolah (apalagi hanya membaca buku ajar) tetapi dituntut untuk mempelajari berbagai sumber belajar, seperti majalah, surat kabar, dan internet. Hal ini penting, agar apa yang dipelajari sesuai dengan kondisi dan perkembangan masyarakat, sehingga tidak terjadi kesenjangan dalam pola pikir peserta didik (Mulyasa, 2013).

Peran guru sangat dibutuhkan dalam meningkatkan kemajuan pendidikan. Setiap pendidikan sangat membutuhkan guru yang kreatif, profesional, dan menyenangkan agar siswa nyaman saat proses pembelajaran, karena di setiap pembelajaran siswa harus benar-benar menguasai bahan atau pelajaran-pelajaran yang diajarkan oleh guru tersebut. Oleh karena itu guru harus bisa mengembangkan sumber belajar, tidak hanya mengandalkan sumber belajar yang 
Citra Juniarni, Abdallah, Helyani

Peran Guru Pendidikan Agama Islam dalam Meningkatkan Perilaku Islami Siswa di SD Negeri 01 Indralaya

sudah ada. Peranan guru dalam meningkatkan prestasi belajar siswa sangat besar sekali. Apabila seorang guru tersebut berhasil dalam merencanakan, merancang, melaksanakan, dan mengevaluasi proses pembelajaran, maka bisa dikatakan berhasil dalam kinerjanya sebagai seorang guru profesional. Di sisi lain dalam lingkup pendidikan Islam guru tidak hanya sekedar merancang pembelajarannya, akan tetapi juga membina dan mengarahkan peserta didik untuk berperilaku terpuji, itulah yang menjadi tanggung jawab guru agama.

Dengan demikian seorang guru pendidikan agama Islam ialah merupakan figur seorang pemimpin yang mana di setiap perkataan atau perbuatannya akan menjadi panutan bagi anak didik, maka di samping sebagai profesi seorang guru agama hendaklah menjaga kewibawaannya agar jangan sampai seorang guru agama melakukan hal-hal yang bisa menyebabkan hilangnya kepercayaan yang telah diberikan masyarakat (M. Ngalim Purwanto, 1988: 169). Di sekolah, disiplin banyak digunakan untuk mengontrol tingkah laku siswa yang dikehendaki agar tugas-tugas sekolah dapat berjalan dengan optimal (Juniarni, Pengantar Manajemen PAUD, 2020). Ahmad Tafsir mengutip pendapat dari Al-Ghazali mengatakan bahwa siapa yang memilih pekerjaan mengajar, ia sesungguhnya telah memilih pekerjaan besar dan penting. Karena kedudukan guru pendidikan agama Islam yang demikian tinggi dalam Islam dan merupakan realisasi dari ajaran Islam itu sendiri, maka pekerjaan atau profesi sebagai guru agama Islam tidak kalah pentingnya dengan guru yang mengajar pendidikan umum (Tafsir, 1992).

Dari pembahasan di atas sangat diperlukan sekali peran guru yang mampu menjadi teladan yang baik bagi siswanya, akan tetapi sebagian besar malah kehilangan komitmennya sebagai pengajar sekaligus pendidik. Oleh karena itu guru Pendidikan Agama Islam diharapkan mampu mengajarkan, membimbing, dan memberikan teladan yang baik kepada siswa tentang bagaimana berperilaku yang baik. Peran guru Pendidikan Agama Islam memiliki posisi sentral dalam membentuk perilaku siswa di sekolah, jika guru mampu mengarahkan siswa untuk berperilaku Islami, bukan tidak mungkin di sekolah tersebut tercipta budaya perilaku Islami.

\section{METODE PENELITIAN}

Penelitian ini menggunakan pendekatan deskriptif kualitatif melalui sudut pandang ilmu pendidikan dengan observasi partisipatif untuk menguraikan, menggambarkan, menggali dan mendeskripsikan tentang peran guru pendidikan agama Islam dalam meningkatkan perilaku Islami siswa di SD Negeri 01 Indralaya. Tidak hanya itu, peneliti juga mengamati secara berkala terhadap fenomena yang tampak, situasi serta kondisi dari objek penelitian yang

11 Print - ISSN: 2443-0021

Online - ISSN: 2716-4136 
informasinya dapat diambil dari berbagai responden dan dokumen-dokumen pendukung lainnya.

Data yang diperoleh berbentuk data primer dan sekunder. Peneliti menggunakan beberapa metode dalam menghimpun data di antaranya: a. metode observasi, metode ini merupakan langkah awal yang peneliti lakukan dengan cara mengamati langsung ke lokasi penelitian mengenai peran guru pendidikan agama Islam dalam meningkatkan perilaku islami siswa di SD Negeri 01 Indralaya; $b$. metode wawancara, metode wawancara dalam penelitian ini bertujuan untuk memperoleh berbagai informasi tentang peran guru PAI dalam meningkatkan perilaku islami siswa serta faktor penghambat dan pendukungnya; dan $c$. metode dokumentasi, metode ini merupakan suatu cara pengumpulan data yang menghasilkan catatan-catatan penting yang berhubungan dengan masalah yang diteliti, sehingga akan memperoleh data yang lengkap, sah dan bukan berdasarkan perkiraan. Oleh sebab itu, untuk memperoleh data tertulis secara optimal, maka penulis menggunakan metode dokumentasi ini dengan tujuan untuk mengumpulkan data tertulis tentang peran guru PAI dalam meningkatkan perilaku islami siswa.

Analisis data yang digunakan pada penelitian ini yaitu model Miles dan Huberman. Data-data yang dianalisis melalui beberapa tahapan-tahapan, sebagaimana yang dikemukakan Miles \& Huberman (1984) bahwa aktivitas dalam analisa data, yaitu data reduction, data display, dan conclusion drawing/ verification.

\section{HASIL DAN PEMBAHASAN}

Hasil penelitian diuraikan dengan urutan berdasarkan pada subyek penelitian, yaitu data hasil penelitian dari sumber data yang terdiri dari informan dan data observasi serta dokumentasi. Sajian data hasil penelitian, berdasarkan hasil wawancara mendalam dengan informan dan data tambahan dari observasi dan dokumentasi secara ringkas. Berdasarkan observasi awal yang dilakukan oleh peneliti di SD Negeri 01 Indralaya, perilaku Islami siswa sangat terasa saat berada di lokasi penelitian, karena di sana peneliti melihat kegiatan-kegiatan keagamaan seperti membaca surat Yasin bersama, dilanjutkan dengan doa, yang dilaksanakan setiap hari Jumat pagi sebelum melaksanakan aktivitas belajar mengajar. Selain itu para siswa hampir merata mengucapkan salam ketika memasuki kelas dan bertemu dengan orang lain (tamu). (Obs. 21/9/2020).

\section{Peran Guru PAI Dalam Meningkatkan Perilaku Islami Siswa di SD Negeri 01 Indralaya}

Berdasarkan hasil temuan yang telah dibahas pada pembahasan sebelumnya, diketahui bahwa perilaku islami siswa SD Negeri 01 Indralaya sudah terlihat jelas 
Citra Juniarni, Abdallah, Helyani

Peran Guru Pendidikan Agama Islam dalam Meningkatkan Perilaku Islami Siswa di SD Negeri 01 Indralaya

dalam kesehariannya di sekolah, baik dalam bidang ibadah maupun bidang akhlak. Dalam bidang ibadah seperti shalat berjamaah, membaca Al-Quran yang merupakan contoh-contoh kegiatan yang sudah biasa dilakukan oleh siswa secara rutin. Sedangkan dalam bidang akhlak, seperti mengucapkan salam baik bertemu dengan guru ataupun sesama siswa, menghormati dan mematuhi setiap nasehat baik berupa perintah maupun larangan yang diberikan oleh guru, maupun dari sekolah.

Perilaku islami yang ditunjukkan oleh siswa SD Negeri 01 Indralaya tersebut tidak terlepas dari pada peran guru sebagai pendidik yang tidak mengenal lelah untuk membina dan membentuk perilaku Islami pada siswa. Dari hasil temuan peneliti dalam observasi terkait perilaku islami, maka dibutuhkan peran guru untuk membentuk perilaku islami tersebut. Adapun peran yang dilakukan guru PAI di SD Negeri 01 Indralaya dalam membentuk perilaku islami siswa, adalah sebagai berikut:

\section{a. Guru Menggunakan Metode untuk Membentuk Perilaku Islami Siswa}

Secara garis besar ada beberapa aspek yang harus diperhatikan oleh guru PAI dalam membentuk dan meningkatkan perilaku Islami pada siswa, karena keberhasilan dari tujuan guru sangat bergantung dari strategi maupun langkah yang diterapkan, serta aspek apa saja yang harus di perbaiki dan diubah. Berdasarkan hasil wawancara mendalam Indepth Interview peneliti dengan Guru Pendidikan Agama Islam yakni ibu Su'aibah, S.Pd.I menyatakan bahwa sebagai guru PAI selalu berusaha untuk membimbing para siswa-siswi untuk berperilaku islami atau berperilaku dengan baik, atau mengingatkan jika para siswa/i melakukan perbuatan yang tidak terpuji, saya juga selalu berusaha untuk lebih dekat dengan mereka untuk membangkitkan semangat dan memotivasi mereka agar selalu rajin beribadah, karena menurut saya berangkat dari hal kecil itulah secara tidak langsung mereka akan sadar dan meniru kebiasaan berperilaku islami”. (Ww. Guru PAI. Suaibah. 21/9/20).

Pernyataan guru pendidikan agama Islam di atas bahwasanya sudah mempunyai peran dalam membentuk perilaku islami siswa di SD Negeri 01 Indralaya. Adapun untuk memahami perilaku islami berdasarkan konsep Islam, terlebih dahulu akan peneliti paparkan tentang gambaran dari perilaku yang dapat dilihat pada klasifikasi tingkah laku individu berikut: $a$. Kognitif, yaitu tingkah laku yang berhubungan dengan pengenalan atau pemahaman tentang diri dan lingkungannya (fisik, sosial, budaya, dan agama). Dengan demikian tingkah laku jenis ini merupakan aspek kemampuan intelektual individu, seperti mengetahui sesuatu, berpikir, memecahkah masalah, mengambil keputusan, menilai dan

13 Print - ISSN: 2443-0021

Online - ISSN: 2716-4136 
meneliti, b. Afektif, yaitu tingkah laku yang mengandung penghayatan suatu emosi atau perasaan tertentu. Contohnya: ikhlas, senang marah, sedih, menyayangi, mencintai, menerima, menyetujui, dan menolak, c. Konatif, yaitu tingkah laku yang terkait dengan dorongan dari dalam dirinya untuk mencapai suatu tujuan (sesuatu yang diinginkan), seperti niat, motif, cita-cita, harapan, dan kehendak dan, $d$. Motorik, yaitu tingkah laku yang berupa gerak-gerik jasmaniah atau fisik, seperti: berjalan, berlari, makan, minum, menulis, dan berolahraga (Yusuf, 2005).

Dari kajian teori di atas, Agama Islam memerintahkan bahwa guru tidak hanya mengajar saja melainkan lebih dalam kepada mendidik. Di dalam merefleksikan pembelajaran, seorang guru harus mentransfer dan menanamkan rasa keimanan sesuai dengan yang diajarkan agama Islam seperti yang telah diterapkan oleh guru pendidikan agama Islam di SD Negeri 01 Indralaya memang sudah benar adanya.

\section{b. Membudayakan 5S Pada Siswa}

Adapun dalam membentuk perilaku Islami pada siswa, guru PAI harus menentukan langkah-langkah yang tepat agar apa yang menjadi tujuan dari guru dapat tercapai secara maksimal. Seperti yang dilakukan oleh guru PAI dengan membudayakan 5S yaitu salam, senyum, sapa sopan dan santun dalam berperilaku.

Berdasarkan dari hasil observasi yang peneliti lakukan di SD Negeri 01 Indralaya memang benar adanya ketika guru masuk kelas dengan mengucapkan salam kepada siswa/i, setelah itu guru menyuruh ketua kelas untuk memimpin doa, dilanjut dengan mengabsen siswa setelah itu melakukan apersepsi kurang lebih 10 menit. Setelah apersepsi guru menjelaskan materi hari ini dan memberikan tugas-tugas yang berkaitan tentang materi yang dipelajari. (Obs. 21/9/20).

Data penelitian dari observasi di atas dapat peneliti kemukakan bahwa sebelum proses pembelajaran dimulai, guru PAI selalu mengucapkan salam dan menyuruh ketua kelas untuk memimpin doa, hal tersebut dapat menjadi teladan yang baik bagi siswa. Adapun hasil observasi yang dilakukan oleh peneliti di atas diperjelas dengan ungkapan yang dinyatakan oleh ibu kepala sekolah yakni Ibu Indramulya menerangkan bahwa para guru di SD Negeri 01 Indralaya ini memang secara tidak langsung sudah membudayakan 5S yakni salam, senyum, sapa, sopan dan santun. Penerapan 5S ini dibudayakan tidak di dalam kelas, akan tetapi di luar kelaspun juga sudah diterapkan oleh setiap guru agar menjadi contoh bagi siswa dan siswi di sekolah ini, dan harapannya bisa diterapkan oleh para siswa juga di rumah dan di lingkungan masyarakat. (Ww. KS. Indramulya. 21/9/2020). 
Citra Juniarni, Abdallah, Helyani

Peran Guru Pendidikan Agama Islam dalam Meningkatkan Perilaku Islami Siswa di SD Negeri 01 Indralaya

\section{c. Memaksimalkan Fasilitas Keagamaan}

Selain membudayakan 5S guru Pendidikan Agama Islam di SD Negeri 01 Indralaya juga memaksimalkan fasilitas keagamaan seperti ruangan untuk praktik ibadah dan buku-buku islami untuk kajian-kajian tentang Islam agar para siswa semakin luas pengetahuannya terhadap agama Islam. Menurut Ahmadi dan Supriyono dalam bukunya Wahyudin peran guru dalam proses belajar berpusat pada: a. Mendidik anak dengan memberikan pengarahan dan motivasi untuk mencapai tujuan, baik tujuan jangka pendek maupun tujuan jangka panjang; b. Memberi fasilitas, media, pengalaman belajar yang memadai; c. Membantu mengembangkan aspek-aspek kepribadian siswa, seperti sikap, nilai-nilai, dan penyesuaian diri (Nasution, 2011).

Di sekolah ini ada kegiatan-kegiatan yang namanya kegiatan keagamaan seperti membaca surat yasin bersama, dilanjutkan dengan doa, yang dilaksanakan setiap hari Jumat pagi sebelum melaksanakan aktivitas belajar mengajar, dan biasanya kita gunakan ruangan kelas untuk praktik ibadah tersebut. Selain itu kita juga gunakan buku-buku yang ada di sekolah ini untuk mendapatkan nilai-nilai islami yang bisa diajarkan kepada siswa di SD ini. (Ww. Guru PAI. Su'aibah. 21/9/20)

Dari wawancara di atas terlihat bahwa begitu pentingnya peran seorang guru pendidikan agama Islam dalam menyusun strategi agar siswa-siswinya dapat berperilaku islami dengan menggunakan fasilitas yang ada di sekolah tersebut.

\section{d. Guru yang Teladan Bagi Siswa}

Begitu sentralnya peran guru dalam mendidik siswa maka dibutuhkan integritas dan komitmen dari seorang guru, terlebih lagi sebagai guru pendidikan agama Islam, mengapa demikian karena dalam pendidikan Islam guru juga memiliki peran penting dalam membina perilaku siswa sehingga terbentuk akhlak yang baik dan menjadi perilaku Islami di keseharian para siswa. Di samping itu guru Pendidikan Agama Islam adalah figur atau contoh teladan yang diharapkan mampu menanamkan perilaku Islami kepada siswanya agar terbentuk akhlak yang baik, sehingga budaya perilaku islami menjadi kebiasaan baik sehari-hari.

Hasil temuan peneliti dalam wawancara dan observasi langsung ke lapangan yakni di SD Negeri 01 Indralaya terdapat peran guru untuk meningkatkan perilaku Islami pada siswa, salah satunya adalah dengan menjadi model atau teladan. Hal ini dijelaskan oleh guru di SD Negeri 01 Indralaya yakni ibu Rismiyati, S.Pd.I dalam wawancara bahwa tidak hanya guru pendidikan agama Islam saja yang harus menjadi teladan yang baik akan tetapi seluruh guru yang mengajar mata pelajaran lainnya juga harus selalu berusaha memberikan teladan yang baik bagi siswa sebaik mungkin agar para siswa bisa mencontoh dan menerapkan apa

15 Print - ISSN: 2443-0021

Online - ISSN: 2716-4136 
mereka lihat dan yang telah diajarkan dalam kehidupan sehari-hari. (Ww. Guru. Rusmiyati. 24/9/2020).

Pernyataan ini diperkuat dengan observasi yang dilakukan peneliti terkait sikap keteladanan guru di SD Negeri 1 Indralaya ditunjukkan dengan memberikan keteladanan seperti selalu mengucapkan salam baik bertemu di jalan maupun ketika memulai pembelajaran, pada saat pelajaran akan dimulai guru juga memimpin siswa untuk berdoa, selain itu pada akhir pembelajaran guru selalu memberikan motivasi kepada siswa untuk selalu berperilaku terpuji. Terlihat juga ke teladan guru PAI dari kedisiplinan dan tanggung jawab yang diperlihatkan guru pada saat mengajar maupun di luar jam pelajaran. Hal tersebut yang akhirnya secara tidak langsung ditiru oleh siswa dan menjadi budaya yang baik dalam berperilaku. (Obs. 24/9/20)

Menurut peneliti pernyataan dalam wawancara di atas dengan mencontohkan perilaku islami atau perilaku baik yang dicontohkan oleh guru di SD Negeri 01 Indralaya sudah benar dikarenakan dengan menjadi model atau teladan guru akan dapat menanamkan perilaku Islami pada siswa secara maksimal. Siswa secara tidak langsung akan mencontoh segala yang dilakukan oleh guru, dan itu merupakan salah satu cara yang efektif dalam meningkatkan perilaku islami siswa. Dengan menjadi model atau teladan, diharapkan tumbuh kesadaran dari Siswa untuk berperilaku Islami. Oleh karena itu seorang guru harus menyadari apa kekurangan dan apa yang harus dilakukan untuk meningkatkan perilaku Islami pada Siswa.

Hal di atas tersebut sebagaimana diungkapkan oleh Nurdin bahwa Guru yang baik adalah yang menyadari kesenjangan antara apa yang diinginkan dengan apa yang ada pada dirinya, kemudian menyadari kesalahan ketika memang bersalah. Kesalahan harus diikuti dengan sikap merasa dan berusaha untuk tidak mengulanginya (Nurdin, 2010).

Sardiman menjelaskan dalam bukunya Interaksi dan Motivasi Belajar Mengajar bahwa agar menjadi seseorang yang diteladani atau dalam artian panutan tidaklah mudah, sehingga seorang guru terlebih dahulu harus memahami dan melakukan pendekatan terhadap siswanya dengan tujuan menciptakan hubungan yang lebih erat sehingga akan tercipta pengertian dan pemahaman antar kedua belah pihak secara alamiah. Maksudnya, seorang guru harus berupaya menjadi seorang sahabat bagi siswanya terutama siswanya tang tergolong remaja usia sekolah menengah yang masih tergolong labil dan dalam proses penyesuaian diri atau pencaharian jati diri, dengan peran guru sebagai sahabat maka intensitas serta kualitas hubungan diantara keduanya akan lebih erat terjalin (Sardiman, 2001: 62).Sebagai teladan, tentu saja pribadi dan apa yang dilakukan guru akan 
Citra Juniarni, Abdallah, Helyani

Peran Guru Pendidikan Agama Islam dalam Meningkatkan Perilaku Islami Siswa di SD Negeri 01 Indralaya

mendapat sorotan para siswa serta orang di sekitar lingkungannya yang menganggap atau mengakuinya sebagai guru.

Dari beberapa hasil temuan pada penelitian ini ada empat hal peran yang dilakukan oleh guru PAI untuk meningkatkan perilaku islami siswa di SD Negeri 01 Indralaya yaitu: Pertama, yakni menggunakan metode selalu berusaha membimbing siswa-siswi untuk berperilaku dengan baik, mengingatkan jika mereka melakukan perbuatan yang tidak terpuji serta mengajak berdoa bersama. Kedua, memaksimalkan fasilitas keagamaan di sekolah seperti ruangan untuk praktek ibadah dan buku-buku islami. Ketiga, Membudayakan 5S yakni memberikan contoh nyata pada saat kegiatan belajar mengajar seperti selalu mengucapkan salam, senyum, sapa, sopan dan santun. Keempat, selalu berusaha memberikan contoh yang baik atau teladan bagi siswa agar para siswa memberikan timbal balik yang baik pula dalam kehidupan sehari-hari serta mengingatkan siswa untuk berbuat baik, maka secara tidak langsung siswa akan meneladani apa yang dicontohkan oleh gurunya.

\section{Faktor Pendukung Dan Penghambat Guru PAI dalam Meningkatkan Perilaku Islami Siswa di SD Negeri 01 Indralaya}

Peran guru pendidikan agama Islam dalam meningkatkan perilaku Islami siswa di SD Negeri 01 Indralaya memiliki beberapa faktor yang mendukung dan menghambat. Adapun faktor pendukung dan penghambat bagi guru pendidikan agama Islam dalam meningkatkan perilaku Islami siswa di SD Negeri 01 Indralaya akan diuraikan sebagai berikut:

\section{Faktor Pendukung}

Faktor pendukung bagi guru pendidikan agama Islam dalam meningkatkan perilaku Islami siswa dapat dilihat dalam hasil wawancara peneliti dengan ibu Su'aibah, S.Pd.I dinyatakan bahwa faktor pendukung para guru di sekolah ini dalam meningkatkan perilaku Islami siswa ialah jika para orang tua siswa di rumah juga ikut dalam pembinaan akhlak anak serta mendukung pihak sekolah apabila anak-anak mereka melanggar diberikan sanksi dengan tujuan hanya untuk mendidik agar lebih disiplin. Kemudian dengan adanya kerja sama antar guru dan kepala sekolah dalam hal mempersiapkan anak agar kedepannya lebih menguasai, memahami dan menerapkan ilmu agama di kehidupan masa depannya nanti agar tingkat kualitas pengajarnya tidak diragukan lagi. (Ww. Suaibah. 21/9/2020)

Selanjutnya pernyataan guru pendidikan agama Islam di SD Negeri 01 Indralaya tersebut diperkuat dengan hasil wawancara peneliti bersama kepala sekolah diungkapkan sebagai berikut: Faktor pendukungnya mayoritas tergolong dari fahamnya para orang tua siswa tentang pentingnya pembinaan akhlak yang

17 Print - ISSN: 2443-0021

Online - ISSN: 2716-4136 
baik bagi anak, selain itu para orang tua siswa berkeinginan menanamkan, menambah nilai keagamaan, dan meningkatkan pendidikan agama anak di rumah dan di lingkungan masyarakat. Dengan demikian, para orang tua siswa sangat mendukung dengan adanya pembinaan akhlak yang baik tersebut. (Ww. KS. Indramulya. 21/9/20.

Dengan demikian dapat disimpulkan bahwa faktor pendukung guru pendidikan agama Islam dalam meningkatkan perilaku Islami siswa di SD Negeri 01 Indralaya ialah: Dalam mendukung pengembangan perilaku islami siswa harus ada kerja sama antar guru, karena dengan adanya kerja sama yang baik dan terkoodinir maka pendidik dan orang tua bisa saling bertukar pendapat untuk membicarakan masalah siswa baik di rumah maupun masalah siswa di sekolah dengan adanya kerja sama tersebut maka pendidik memiliki kebebasan dalam mendidik di sekolah sehingga masalah yang dialami oleh siswa bisa diatasi dan saling membantu sama lain.

Partisipasi para orang tua siswa tentang pentingnya pendidikan agama atau pembinaan akhlak siswa juga memiliki peranan penting karena orang tualah yang sangat paham dan mengerti dengan keadaan anak. Dan orang tualah yang pertama kali memberikan didikan atau membentuk perilaku keagamaan anak sehingga orang tua harus sungguh-sungguh dalam mendidik anaknya. Partisipasi orang tua siswa semuanya bertujuan untuk mempersiapkan anak agar kedepannya lebih menguasai, memahami dan menerapkan ilmu agama serta berperilaku islami di kehidupan masa depannya nanti.

Adanya sanksi merupakan suatu teguran yang diberikan guru kepada siswa yang melanggar peraturan sekolah agar siswa tidak mengulanginya lagi. Seperti: memberikan hukuman berupa membersihkan halaman sekolah, memungut sampah dan menyapu ruang kelas apa bila siswa terlambat, memberikan surat kepada orang tua siswa apa bila sudah beberapa tidak masuk sekolah tanpa keterangan (alfa) berturut turut tanpa ada pemberitahuan maka diberikan teguran pertama, kedua, ketiga dan setelah itu jika siswa masih mengulang kesahannya dan sama sekali tidak berubah maka siswa bisa langsung dikeluarkan dari sekolah apa bila poin pelanggarannya sudah tidak terhingga.

\section{Faktor Penghambat}

Mengenai tentang peran guru pendidikan agama Islam dalam meningkatkan perilaku Islami siswa di SD Negeri 01 Indralaya memiliki beberapa faktor penghambat. Menurut ibu Su'aibah sebagai guru pendidikan agama Islam mengungkapkan dalam wawancara bahwa tentang hambatan atau kekurangan pasti ada, contohnya saja di SD Negeri 01 Indralaya ini kurang memadai fasilitasnya seperti tidak adanya musholla, perpustakaan untuk persediaan tentang kajian-kajian Islam atau cerita-cerita Islami memang sudah ada tetapi jumlahnya 
Citra Juniarni, Abdallah, Helyani

Peran Guru Pendidikan Agama Islam dalam Meningkatkan Perilaku Islami Siswa di SD Negeri 01 Indralaya

masih sedikit (Ww. Su'aibah. 21/20). Menciptakan perpustakaan yang bersih, rapi, indah, serta menciptakan kondisi yang menyenangkan baik bagi guru maupun untuk siswa berada di perpustakaan merupakan manajemen sarana dan prasarana yang baik. Di samping itu juga diharapkan tersedianya alat-alat fasilitas belajar yang memadai secara kuantitatif, kualitatif, dan relevan dengan kebutuhan serta dapat dimanfaatkan secara optimal untuk kepentingan proses pendidikan dan pengajaran baik oleh guru maupun untuk siswa (Juniarni, et al., 2020)

Pernyataan di atas dapat dilihat bahwa selain tidak adanya musholla, SD Negeri 01 Indralaya pun minim buku kajian-kajian Islam atau buku cerita yang islami, dalam hal ini sangat disarankan kepada SD Negeri 01 Indralaya untuk pengadaan fasilitas yang merupakan suatu referensi dalam mengembangkan perilaku islami siswa, karena dengan adanya buku keagamaan tersebut siswa akan mudah untuk belajar sendiri di rumah maupun di sekolah.

Dijelaskan dan ditambahkan juga oleh ibu Rusmiyati dalam kutipan wawancara yang menyatakan bahwa faktor penyebabnya adalah kesibukan sebagian kecil dari para orang tua siswa yang tidak sempat meninjau kegiatankegiatan bermain anak dalam artian pembinaan akhlak anak ketika di rumah dan tidak sempat meninjau tempat belajar anak dan menyerahkan sepenuhnya pendidikan anak kepada sekolah. (Ww. KS. Rusmiyati. 24/9/20).

Salah satu tempat ibadah adalah Mushallah yang memiliki peran penting dalam membentuk perilaku islami siswa, namun pada kenyataannya di SD Negeri 01 Indralaya tersebut tidak memiliki mushollah sehingga proses pembentukan perilaku islami terhambat, seperti melaksanakan ibadah shalat, tarbiyah dan baca tulis alquran.

Berdasarkan hambatan guru pendidikan agama Islam dalam membentuk perilaku islami siswa di atas maka upaya yang dilakukan oleh guru PAI dalam membentuk perilaku islami siswa adalah: Guru menggunakan metode ceramah dan metode pembiasaan untuk membentuk perilaku islami, guru mengenali perubahan emosi siswa dengan melihat dan memahami perilaku islami siswa, mengontrol siswa dalam menjaga perilaku islami, pengembangan perilaku islami melalui pelajaran Pendidikan Agama Islam, serta memberikan hukuman.

Faktor hambatan yang diungkapkan para informan di atas, menurut peneliti merupakan suatu persoalan yang harus dibenahi agar pengembangan perilaku islami siswa di SD Negeri 01 Indralaya dapat teratasi dan dapat berjalan dengan baik.

19 Print - ISSN: 2443-0021

Online - ISSN: 2716-4136 


\section{KESIMPULAN DAN SARAN}

Upaya yang dilakukan oleh seorang guru pendidikan agama Islam adalah bekerja sama dengan guru-guru lainnya untuk memberikan pengarahan dan teladan kepada siswa seperti melakukan sholat berjamaah bersama dan memberikan pencerahan kalbu secara rutin yang tidak hanya di dalam kelas akan tetapi di luar kelas pun kesehariannya selalu dibimbing dan diarahkan untuk berperilaku islami dan siswa mampu memperbaiki ibadahnya. Selain itu, diperlukan juga untuk pembangunan musholla agar pihak sekolah bisa mengontrol dan membimbing ibadah siswa. Dan terkait akhlak siswa yang masih bermasalah maka diperlukan pembinaan akhlak untuk mengarahkan siswa menjadi lebih baik.

\section{REFERENSI}

Djamarah, S. B. (1994). Prestasi Belajar dan Kompetensi Guru. Surabaya: Usaha Nasional.

Juniarni, C. (2018). Partisipasi Orang Tua dalam Pendidikan Baca Tulis AlQur'an. Jurnal ITIBAR, 25.

Juniarni, C. (2020). Pengantar Manajemen PAUD. Jambi: Penerbit Qiarra Media.

Juniarni, C., Djudddah, H., Rochbani , I., Abidin, Z., Novita, M., Aprianto, I., et al. (2020). Manajemen Perpustakaan Sekolah. Jambi: Qiara Media.

Muhaimin. (2006). Nuansa Baru Pendekatan Islam. Jakarta: PT. Raja Grafindo.

Mulyasa. (2013). Menjadi Guru Profesional Menciptakan Pembelajaran Kreatif. Bandung: PT. Remaja Rosdakarya.

Nasution, W. N. (2011). Teori Belajar dan Pembelajaran. Medan: Perdana Publishing.

Nurdin, M. (2010). Kiat Menjadi Guru Profesional. Yogyakarta: AR. Ruzz Media Group.

Tafsir, A. (1992). Ilmu Pendidiakn dalam Persepektif Islam. Bandung: Remaja Rosdakarya.

Tohirin. (2006). Psikologi Pembelajaran Pendidikan Agama Islam. Jakarta: PT. Raja Grafindo.

Yusuf, S. (2005). Psikologi Belajar Agama: Persepektif Agama Islam. Bandung: Pustaka Bani Quraisy. 